\title{
Lef Nosi and the Albanian Issue during the Days of the Peace Conference (1919)
}

\author{
Enkeleida (Agaçi) Nosi
}

\author{
Doi:10.5901/ajis.2015.v4n3s1p600
}

The 1918-th was the last year of the First World War. During the time of the global conflict Albania, occupied by the Austrian, Greece, Italian, French and Serbian-Montenegrin forces, rather than a state it looked like a wild arena of battles and despoliations where the destiny of the country was determined not only by the course of the war but by the policy of the interested Powers of that time. Albania, proclaimed a neutral state by the Great Powers themselves, would underwent much than combatant parties. Meanwhile the World War was near its end, Lef Nosi moved out to Italy. The economic difficulties were not the unique circumstances that obliged him to be exiled toward the occidental neighbor. During that time (1918) the relationship between Albanians people and Italian forces in the country were rather reformed. By the other side the entrance of the USA in the world conflict, in favor to the Antanta group, paled the danger that came from the application of the Secret Tractate of London (26 April 1915), assurance that came by the declaration of the American President, W. Wilson, that neither nation must not aim to choose its own governance to one other nation. ${ }^{1}$

From Italy Lef Nosi, together with other Albanians personalities, followed carefully the evolution of the events in Albania where little by little the Austrian-Hungarian effectives and Bulgarian forces were going and were cantoning the Italian and Serbian commands. But the presence of the Serbian forces awoke to Lef Nosi's memory, like to many other Albanian people, their barbarism and violence versus the innocent Albanian people during 1913-th and after. Like a politician, a connoisseur and a researcher of the history of Albanian lands, for him was generally known the historical Cetinja dream to enlarge its southerner frontier aboard the Albanian lands. At the same time he looked one other fatality by the presence of Serbian forces in the country that was connected with their support for Esat Pasha Toptani and its followers during 1915-th. By the 1913-th Lef Nosi, diplomatized, was tried to limited the Esat Toptani's activity and to avoided the fratricide war between Albanians. But the pacific behavior had not give the requisite results and Esat Pasha had attempted, with the support of the northern neighbor, to usurped the headship of the Albanian state.

At this flash point, when the serbian forces were came back to the albanian lands, prevailed the dubiety that their advance could invite the reinstatement of Esat Toptani and his exponents in Albania. Lef Nosi decided to finish its continuance in Italy just at the time when the austrian-hungarian forces run away from Elbasan city in October 1918-th. At that time he secured the authorization by the italian government to be repatriated. Teamwise with other albanians that were there, he put out from Taranto, with a military cruiser, towards to Valona city and from there he get a move on the Elbasan city. ${ }^{2}$

By the September the austrian armies had begun to retired northwardly and their hiatus were taken by the italian armies that expanded their invasion during all the Median Albania and over the better part of the Nothern Albania. At 11 November 1918 the World War was finished.

By the ending of the First World War the situation in Albania was not in coherence with its international status decided in 1913-th, at the Ambassadors Conference in London. Major part of its territory was under the control of italian forces, the frenches kept invaded the region of Korça, the serbian forces were formed across the strategic line, while in Shkodra re-established the international administration condected by French colonel De Forthou. At these conditions the country was immersed in a real chaos and in a deep misery. The Albanian occupied in every edge had not any sign of autonomy or a government that could represent itself in front of winning states to ask its vitals rights. The heavy politic situation, with the concluding of mondial conflict, was overweighting the new risks which were appeared not only about the defense of confines, but about the re-established of its politic dependences too. The evolution of diplomatic performance at the international arena re-activated the Albanians patriotic circles, inside and outside the country, for whom were known the plans and the projects composed during the war and which were waiting to realized by the Peace Conference.

\footnotetext{
1 Swire, Joseph, Albania..., Tirana, 2005, pg. 219

${ }^{2}$ Frashëri, Mehdi, Kujtime, Tirana, 2005, pg. 51
} 
Being in such position, the Albania had an immediate necessity for a representative government that could be created by a national assembly. Exulted by the Italian support, since it wanted to erectiled Albania- under its controlinside widest confines if it's possible, ${ }^{3}$ the national movement introduced the request to organized a meeting with delegates by different parts of Albanian land. After a lot of hesitations by the Rome, were be able that in December 25, in 1918 in Durrës was held a national Congress. In the Congress partecipated 48 delegates by the different parts of the country, where Elbasan will be repressented by Lef Nosi, Shefqet Vërlaci and Ahmet Dakli. When was convened the Assembly, the Italians insisted to blocked the construction of a government and aimed the construction of a national council, which had to vocalized the desires of Albanian people for whole causes that would be discussed at the Peace Conference about Albania. But the Congress completed its duty with a different result from the Italian request.

At the new government of Turhan Pasha, got out from this congress, Lef Nosi was elected to administrate the Ministry of Food and Economy ${ }^{4}$ being in this case to direct one of the most problematic and the most important issues for Albania that at that time was destroyed by the War and was deplorabled by the economic aspect. Like in 1912-th, at the Temporary Government of Vlora, he would be public-spirited at the new duty in Durrës government.

Besides the politic activity, Lef Nosi didn't stop its researching work in the history area during the difficult times that Albania passed along the First World War. The materials that he gathered and would be published some years later to the Historical Documents to the defense of the national issue were not only testimony of the historical events and annals of that time, but those composed a precious contribution at the Albanian historiography area. On the historical files that he created we find presented the proceedings of the Durrës Congress and the attitudes held in it. In the meeting of the Assambly was also read the letter remittented by Aqif Pashë Elbasani, who insisted to the defense of the Albanian dependence declared in 1913-th at the Ambassadors Conference in London. But the incorporation of prince Wied in germanic army during the war, being classified at the loser powers, did difficult, even better, did impossible its return in Albania. Therefore the main aim of the new government of Durrës was the defense of the Albanian national rights, totally and everywhere lived the Albanian people, inquiry of national confines and complete independence of Albanian state. ${ }^{5}$

To realize the foreign politic of the government, the Congress decided to send its representatives in the new Peace Conference, to represent there the Albanians interests, that in that time were un-presented by Esad Pashë Toptani and his so-called ministers. During the time that the Albanian delegation of the Durrës Government were on their way to Paris, the other part of executive cabinet in country begun the work to realized the executive program. The economic rudiments of Albania were so delicate. Exactly on these rudiments would start its job the Minister of the National Economy, Lef Nosi to perform the projects for saving Albania from the economic destruction even though that was not the only problem he could face.

At this light the Albanian Temporary Government had aimed the conclusion of a settlement with an Italian bank, interposed by the Italian government, by design the construction of a department of this bank in Albania. Permanent firmly into the defense of the national question, public-spirited at war against fraction of Albanian lands, with a precious contribution into protection of cultural and historical values of its nation, Lef Nosi took place at the constellation of the Albanian patriotic movement. Affected for its nationalism, in 1919-th, he was vote from Progress Association of Elbasan city, president of the National Theatre of this city and warden of this Theatre. Exactly at this time, in April 1919-th, Lef Nosi took a letter from the Committee of Korça city about the deportment of frenches forces, which in 28 March 1919, kept down the Albanian national flag. The policy followed by the frenches had hearten Greece forces, united and organized on files along Albanian-greek frontier, which had aimed to enter to Albania, exactly in Korça, by force and theatricalized a rebellious movement that could influence the next decisions of the Peace Conference in Paris.

In the letter were enunciate the political viewpoints existed in Korça about the ways must be followed for saving the country by the risks came from our neighbors. The undecided attitudes of the Albanian delegates in Paris and unalbanian propaganda about installation of foreign protectorate in Albania, seemed diffused unto habitants of this region. We - was wrote in the letter, - have protested into governments of Antanta Powers and to the President of USA, to demand that our commune be connected with our mother Albania under the defense of Italy; but defense doesn't mean protection. 6

But for Lef Nosi, the campaigner of Independent Albania, the Minister of Temporary Government in Vlora (1912-

\footnotetext{
${ }^{3}$ Swire, Joseph, Albania..., Tirana, 2005, pg. 233

${ }_{4}^{4}$ The Albanian Central Archives, Fund. 32, D. 12, pg. 2

${ }^{5}$ Idem

${ }^{6}$ The Albanian Central Archives, Fund. 32, D56, pg. 41
} 
1914), the defender of Albanian state guided by prince Vilhelm de Wied, had not flashback. The Albania had proclaimed its independence in 1912-th and the Great Powers had accepted that the new state amid free countries in 29 July 1913. At that moment this reality was written in the pages of the History with the Albanian blood. This was the political position of Lef Nosi, who represented, at the same time, the patriotic opinion of Elbasan people, that refused the suggestion to celebrate the anniversary of proclamation to the independence of Albania from the Italian authority. The permanence of independent life of Albanian state - was the political repute in Median Albania. We have heard that in Median Albania was wrote by the Committee of Korça, - the opinion of the most of people is against the Italian defense and aimed an independent Albania. This opinion is the best one and every Albanian must be have it... ${ }^{7}$ The unstable opinions of the Albanian representatives in Paris could place in risk the Albanian issue.

After the departure, for health reasons, of the leader of the governmental delegation in Paris - Turhan Pashë Përmeti, the premier of the Albanian government, notably by the reason of warring deportments of Albanian delegates, in June 1919-th were done some fundamental innovations. The presidency of the new delegacy of Albanian Temporary Government in the Peace Conference was taken by Luigj Bumçi, meanwhile Lef Nosi, Mehdi Frashëri and Luigj Gurakuqi were elected new members of the delegacy. Its aim, of new delegation, was to disestablish the separations and different deportments of Albanian representatives in Paris and would followed all along the line of the national program proclaimed at the memorandum of February 12, in 1919-th from the delegacy of the Government in Durrës, that were sent to the Peace Conference in Paris. The new delegacy emphasized like a plank that: We are asking to be entertainer in the Albanian lands which are disembody from our country by the Berlin Tractate and than by the Ambassadors Conference in London (1913); we are asking the independence of Albania and the veneration of the sovereign rights of the Albanian nation. Also we are asking economical recompenses for a lot of burnt villages by the Greece forces at the south Albania and for the destructions that the armies of the Central Monarchies have act in our country during their conquests. So this delegacy aimed to confronted every effort that designed to destroyed the territorial integrality, the independence and the sovereign rights of the Albanian state. ${ }^{8}$

The meeting of July 31, in 1919-th concluded with the incorporation in the governmental delegation of Mihal Turtulli and Mehmet Konica. Than in this meeting was punctuated with regard to the case about admission of the assistance of someone from the Great Powers, the mission will be adjusted in accordance with the requisitions presented until now to the Conference about this case, namely it will ask that the assistance must be temporary and mustn't hurt the sovereign rights of the Albanian state, neither the prosperity and its economical progress. ${ }^{9}$

The news about the Italian- greek collusion of 29 July, increased the inquietude unto Albanian representatives that created a memorandum, where they protest in front of the Fifth Council against every decision that could be taken about the Albanian issue, without discussing it before with them. ${ }^{10}$

Meantime, during the August 1919-th, in Korça city the Greece forces had replaced the frenches effectives and this act announced publicly the habitants. Immediately better part of the people abandoned the region and left to the Italian zone. ${ }^{11}$ With the contradiction of Albanian Government, Korça city passed again under the frenches administration and the habitants begun to came back at their houses. Meanwhile the incident disturbed the people in Elbasan city that, in September 1919-th, protested against the Greece effort to invaded the Korça city: The people in Elbasan city, collected all together, express wondering its sadness and indignation about the evacuation of the frenches authorities, to the people of Korça city which is cleaning out from its habitants now... It will be an awful injustice that this city, that the Conference in London in 1913-th....accept it like an Albanian city, be invaded by Greece forces. At this moment that the Albanians are waiting to be recompensed for the disaffirmed rights in 1913-th, giving back to Albania - the Kosovo and Çamëri territory, they are hearing this notice that inspire the disappearance of Albanian nation. That is why the people in Elbasan city protest against invasion of Korça city by the Greece army and hope that the Peace Conference will take back this injustice that can produce solicitudes and disturbance in Balkan region. ${ }^{12}$

About the situation in Korça city, Lef Nosi was informed from his brother, called Veniamin, during the autumn of 1919-th, who wrote: The habitants of Korça city that were left one and half month ago, now are coming back to their homeland. We hope that all of this can be finish and the Albania issue can be resolve and then we shall be not slaves but

\footnotetext{
7 Ibidem, pg. 42

${ }^{8}$ The Albanian people war..., Tirana, 1975, pg. 120

${ }^{9}$ Ibidem, doc. 195, pg. 292

$10 \mathrm{lbidem}$, doc. 206, pg. 305

11 Swire, Joseph. Albania..., Tirana, 2005, pg. 236

12 The Albanian people war..., Tirana, 1975, pg. 361
} 
owner of our country. ${ }^{13}$ But the heavy situation held on. After a month from the Veniamin letter, Grigor Nosi wrote his brother, Lef Nosi in Paris, about the insecure situation in Korça city: Korça issue is hard to be explain. The frenches commandant, from one side call the refugees, by the other side he tell them that they shall stay till the end of September and then none know whom shall hand over the Korça city. This fact has preoccupied the habitants and all the Albanian people have asked the support of the Italian Government, although they don't know if they have it. ${ }^{14}$ In front of the interposal by the European states in Paris, eventual risks that were appearing for the Albanians by the Balkans neighbors and the evolution of the situation in Albania, in October 9, the governmental delegacy proposed to the Conference a reasonable change in accord with the situation, home needs and the provisos of the Conference in London in 1913-th about the rise of the Albanian state. ${ }^{15}$

During the meetings of the Albanian delegacy in Paris, constantly the members discussed about the deviation of the foreign commission to Albania. At the end of September it was known the American deportment about the Albanian issue by the private negotiations between the expert of the Albanian delegacy, Fuat Bey Zembraku, and the American counselor, Mr. Bukler: The Peace Conference doesn't do any change for the Albanians with regard to the mandate, but if the Albanians want to be safe from a colonial mandate, they must be ask a kind of assistance that incumbent by the American delegacy and be accepted by the Conference. ${ }^{16}$ The official un-pronouncement of this deportment, raised the clouds of suspicion unto some members of the delegacy, in them Lef Nosi expressed his desire to heard those words by Mr. Fuat Bey and than he could make him some other questions and could formed a best idea about the intention of Mr. Bukler. Meantime he insisted to conclude the warring deportments of Albanian representatives in Paris and added that must be prescript the delegates of Istanbul to abandon their opposition which damage our issue. ${ }^{17}$

During the proceedings Lef Nosi did not supported the idea suggested by some members of the delegacy to ask the Conference for choosing forward to Albania of a prince from the noble family of Savoya, like a unique solution to save Albania from an Italian colonial mandate. He added that Albanian delegacy can't ask one another prince until the prince Wied didn't gave the demission or the people deposed him. By the other side he believed that it was better to talked before, about this case, with the government and then we could take a decision about it. Lef Nosi was against the choosing of an Italian prince for one another reason too. By choosing the Italian prince for Albanian throne, the risk for the future of Valona city will be grew up. So he asked guaranty if the prince will be choosing, someone must save the Vlora city from the Italian invasion. At this case, Lef Nosi had the support of Luigi Gurakuqi who asked too that the delegacy must not given up from the defense of the territorial integrality and never must accept the Italian invasion of the Vlora city by an international act... So the delegacy don't have to do anything about the mandate issue, until to be ascertain finally the Albanian confines and can be explained the mandate issue. ${ }^{18}$

During the sessions of the Conference, while the winner states of the first World War were deciding the destiny of the populations, Lef Nosi would present different authentic documents in favor of the rights of the Albanian people, the rights to be free in their lands. After numerous proceedings about finding the ways to save the independence and the sovereignty of Albania, the governmental delegacy decided: 1 . - to insisted at the respectability of the territorial integrity of Albania composed by the Conference in London in 1913-th and to secured the landing of the national requirements... 2. - to be objected versus all the mandates because Albania has proclaimed its independence by the 1912-th. 3. - to limited the space of the Italian assistance being reposed at the decisions of the Ambassadors Conference.

In October the representatives of the Durrës government in Paris presented a protest note to the chairman of the Conference, Mr. Zh. Klemanso, to protest against the plans of the European states, especially against the Italian and Greece plans, at the other words, against the Tittoni-Venizellos concord that daring the territorial integrality and the independence of Albania.

Inter alia in the protest note was wrote: The Albanian delegacy protest against all the decisions that risk the territorial integrality of our country, the independence and the sovereignty of the Albanian people and that are contrary from the justice principles and the rights of the small nations... Meantime the leader of the Albanian representatives in Paris, Luigi Bumçi, confessed the pro Italian orientation of the Albanian delegacy: to protect our rights, that our voice be heard, we must be strong to compelling; Who has not this force could hope to the support of a friend power. If we take a

\footnotetext{
${ }^{13}$ The Albanian Central Archives, F. 32, D. 57, pg. 72

14 Ibidem, pg. 68

15 The Albania History, vol. III, Tirana, 1984, pg. 201

${ }^{16}$ The Albanian people war..., Tirana, 1975, pg. 400

17 Ibidem, pg. 402

18 Ibidem, pg. 404
} 
look around, we can't see any other power that support us against the Greece and Serbian, aside from Italy. ${ }^{19}$

The 1919-th was finishing and the destiny of Albania, bad-involved with the Adriatic issue, continued to be without an answer from the European diplomacy. In this situation the Albanian representatives in Paris composed a memorandum with the suggestions addressed to the Peace Conference about some changes in the decisions of the Ambassadors Conference at the 1913-th, regarding the admission of the Italian right to guaranteed the neutrality of the Albanian state and intended for Albanian prince to the Aosta Duke. It seems that Lef Nosi was in disfavored with these suggestions and this is confirmed by the fact that the memorandum wasn't undersigned by Lef Nosi. ${ }^{20}$ Besides these changes were proposed some other concessions in favor of our neighboring states on purpose to the protection of the territorial integrality of the Albania. Unfortunately these sacrifices were ineffective too. Debacle of the Durrës government is related with the politic situation of the 1920-th when the country had a lot of difficulties, the people were divided, the economical level was lowermost, the illiteracy was very high, and the corruption, inherited by the Ottoman Empire, was an quotidian occurrence. That year finished a crisis decade with conflicts and chaotic situations.

The national convention, collected in January 1920 , took control to the destiny of the country. Disappointed by the fact that the justice and the independence principles were not respected in their case by the Great Powers, convinced the representatives in the Convention that, in the depressed conditions of their country, they must tried by themselves to liberate their country by the foreign invasion and to show the whole world the determination to protect the independence and the territorial integrality of the country. ${ }^{21}$ It's been formed a new government in Tirana city headed by Sulejman Delvina that organized a new delegacy for Paris. While Luigi Bumçi and Mihal Turtulli were called by the Regency Council, Lef Nosi and Mehdi Frashëri, in May 14, 1920, disembarked in Durrës city. In May 18 Lef Nosi arrived in Elbasan city where he remained to be active and attentive toward the politic developments in the region.

\section{References}

The Albanian Central Archives, Fund. 32 "Lef Nosi".

Swire, Joseph. Albania..., Tirana, 2005

Frashëri, Mehdi, Kujtime, Tirana, 2005.

The albanian people war..., Tirana, 1975.

The Albania History, Vol. III, 1984. 